\title{
Coconut Milk Extraction from Frozen Pulp ${ }^{1}$
}

\author{
L. E. Cancel, J. M. Rivera-Ortiz, and E. R. de Hernández ${ }^{2}$
}

\begin{abstract}
Frozen coconut pulp must be heated to obtain an efficient coconut milk extraction. Heating of the pulp before comminution improves the hammer mill efficiency. A temperature ranging from $35^{\circ}$ to $50^{\circ} \mathrm{C}$ yields about $65 \%$ milk with 25 to $30 \%$ fat, and 37 to $38 \%$ total solids. Two methods were used to heat the frozen pulp: immersion in hot water and treating with steam. With both methods loss in pulp weight resulted. When extra water was added during milling to compensate for weight loss, the extraction yield increased to near the expected value of about $65 \%$. The hot water method, i.e., the addition of warm water at about $40^{\circ}$ $\mathrm{C}$, gave as good results as the steam treatment with the addition of water at about boiling temperature $\left(98^{\circ} \mathrm{C}\right)$. The steam treatment method is recommended since it is cleaner.
\end{abstract}

\section{INTRODUCTION}

Many factors affect the extraction of coconut milk, producing variations in its yield and composition (1). In previous laboratory work frozen coconut pulp gave low grade milk and unsatisfactory extraction yield. The need for application of heat to the pulp prior to the milling operation, or to the milled pulp just before pressing, was observed in studies of frozen storage of coconut pulp (2). In raising the temperature of pulp for industrial coconut milk extraction it was necessary to determine the temperature at which the yield of the operation and the quality of the milk are at the optimum level, as well as the most practical procedure for raising the temperature.

\section{MATERIALS AND METHODS}

Coconuts were purchased at the fresh produce market. Only sound nuts were selected for processing. Selected nuts were heated to $153^{\circ} \mathrm{C}$ $\left(307^{\circ} \mathrm{F}\right.$ ) or $13.2 \mathrm{~kg}$ steam pressure for $8 \mathrm{~min}$ in a high pressure vessel (3). The retort was equipped for fast coming-up and instant release of pressure during the operation. After the heat treatment nuts were broken open in a coconut breaking machine (4). Broken nuts were carried by

${ }^{1}$ Manuscript submitted to Editorial Board May 20, 1975.

${ }^{2}$ Food Scientist, Research Assistant, and Assistant Food Technologist, respectively, Food Technology Laboratory, Agricultural Experiment Station, Mayagüez Campus, University of Puerto Rico, Río Piedras, P.R. 
conveyor to a sorting table where the pulp was separated, trimmed, and fed into a washing reel. Clean pulp was weighed in $8.2-\mathrm{kg}$ lots, bagged in polyethylene, and placed in a $-10^{\circ} \mathrm{C}$ freezer. Polyethylene bags used were $38 \times 23 \times 61 \mathrm{~cm}$ in size and $0.038 \mathrm{~mm}$ film thickness. Lots of frozen pulp were taken from the freezer just before processing.

\section{MILLING OF FROZEN PULP}

Pulp was taken from the freezer, weighed, and comminuted while frozen. Pulp recovered from the hammer mill was placed in a steam kettle to which $2.04 \mathrm{~kg}\left(4^{1 / 2} \mathrm{lb}\right)$ of tapwater were added. The pulp was heated to the desired temperature level before the pressing operation. Unheated pulp was pressed to serve as control. Other batches of pulp were heated to raise the temperature in about $10^{\circ} \mathrm{C}$ increments between lots, starting from the temperature of the unheated pulp. The maximum heat level was set at about $70^{\circ} \mathrm{C}$. After heating, coconut milk was extracted by pressing as described later.

\section{MILLING OF PULP THAWED WITH HOT WATER}

Pulp taken from the freezer was weighed and placed in a steam kettle containing boiling water. Four different hot water treatments were used: immersion of pulp in hot water for $1,3,5$, and $10 \mathrm{~min}$. Heated pulp was placed through the hammer mill where the corresponding amount of water was added. In the first set of experiments $2.04 \mathrm{~kg}$ of tapwater were added; and in the second, $2.04 \mathrm{~kg}$ plus the amount lost during the hot water treatment. Water temperature for the second set was about $40^{\circ} \mathrm{C}$.

Comminution for all the experiments was carried out in a hammer mill equipped with a No. 3 screen $(36,3.1$-mm-diameter perforations in 6.45 $\left.\mathrm{cm}^{2}\right)$. After milling, pulp was recovered from the hammer mill as quantitatively as possible and weighed.

Comminuted pulp was pressed by the rack and cloth method. The milk was separated with a hydraulic press using two nylon press-cloths and aluminum press-racks. Appropriate quantities of comminuted pulp were wrapped first in a finely- and then in a coarsely-woven nylon cloth. The prepared packs were loaded on the press platen, placing a press-rack between packs to provide drainage for milk pressed out during the operation. Pressure in the machine was raised slowly to a gauge reading of 27.2 metric tons ( 30 tons) and maintained for 1 min to provide gradual release of the milk. The pressure in the system used is equivalent to 13.0 $\mathrm{kg} / \mathrm{cm}^{2}\left(185 \mathrm{lb} / \mathrm{in}^{2}\right)$ on the comminuted coconut pulp. Thermocouples were placed in each pack to register pulp temperature while pressing. Coconut milk and press-cake were carefully collected to insure total recovery of both products. Both were weighed and samples were separated for chemical analysis. 
MILLING OF PULP THAWED WITH STEAM

Pulp taken from the freezer was treated with live steam for 1,3 , and 5 min. The heated pulp was placed through the hammer mill where the corresponding amount of water was added. In the first set of experiments $2.04 \mathrm{~kg}$ of tapwater were added. For the second and third set of experiments the amount of water added was $2.04 \mathrm{~kg}$ plus the amount lost during the steam treatment. The added water temperature was about $40^{\circ} \mathrm{C}$ for the second set of experiments and $98^{\circ} \mathrm{C}$ for the third.

\section{RESULTS AND DISCUSSION}

The results of the coconut milk extractions and analysis of press-cake and milk are presented in table 1. Figure 1 shows the effect of temperature on the yield of coconut milk extracted. Comminuted coconut pulp should be above $35^{\circ} \mathrm{C}$ to obtain maximum yields. The temperature range of $20^{\circ}$ to $35^{\circ} \mathrm{C}$ is the most critical. Below this range extractions are below 25\%; and above, extraction climbs to $63 \%$. Results show that raising the temperature above $50^{\circ} \mathrm{C}$ does not increase extraction efficiency.

The advarrtages of heating the comminuted coconut pulp to around $35^{\circ} \mathrm{C}$ are also shown in figures 2 and 3 . Fat content in coconut milk increases with temperature, showing a pronounced change in the range $20^{\circ}$ to $35^{\circ} \mathrm{C}$. Fat content in the press-cake is affected in the opposite way. Solids in coconut milk (fig. $3, \mathrm{~B}$ ) show the same tendency exhibited by the fat content in milk except that it is about $8 \%$ above the fat content (dotted curve). This increase in solid content is attributed to nonfat solids which are found in coconut milk.

Two possible methods for heating the pulp to obtain the desired temperature level in the comminuted pulp were studied: hot water immersion and steam heating of the frozen coconut pulp, two unit operations which are common practice in industrial food processing. The results are shown in table 2 . The effect of immersion of frozen coconut pulp in hot water for $0,1,3,5$, and $10 \mathrm{~min}$ is shown by the continuous line in fig. 4, A. The broken line, for comparative purposes, presents the corresponding values of the previous study (fig. 1). During hot water immersion coconut pulp loses weight; when additional water is used to compensate for this loss, extraction efficiency increases as shown by fig. 4, B.

Treating frozen coconut pulp with steam for $0,1,3$, and 5 min gives much lower yields than expected, as shown by curves in figure $4, \mathrm{C}$. In this treatment there is also a loss of pulp weight. When the weight lost is compensated with additional water, extraction increases to acceptable levels. This improvement in yields is obtained only if the water added is at a temperature of about $98^{\circ} \mathrm{C}$, as shown by curves in figs. $4, \mathrm{D}$ and $4, \mathrm{E}$. 
TABLE 1.-Effect of the temperature of comminuted pulp on the extraction of coconut milk

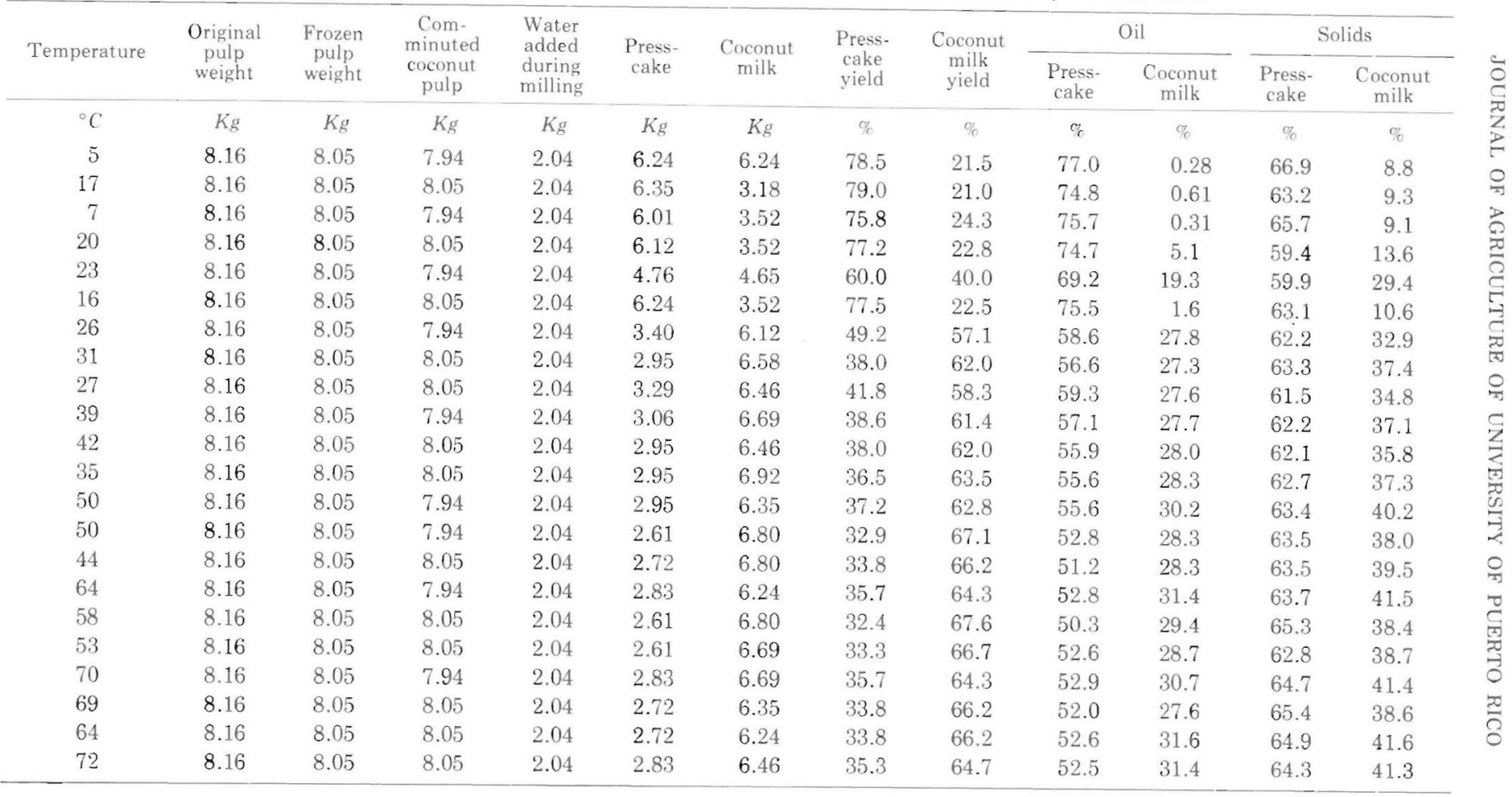




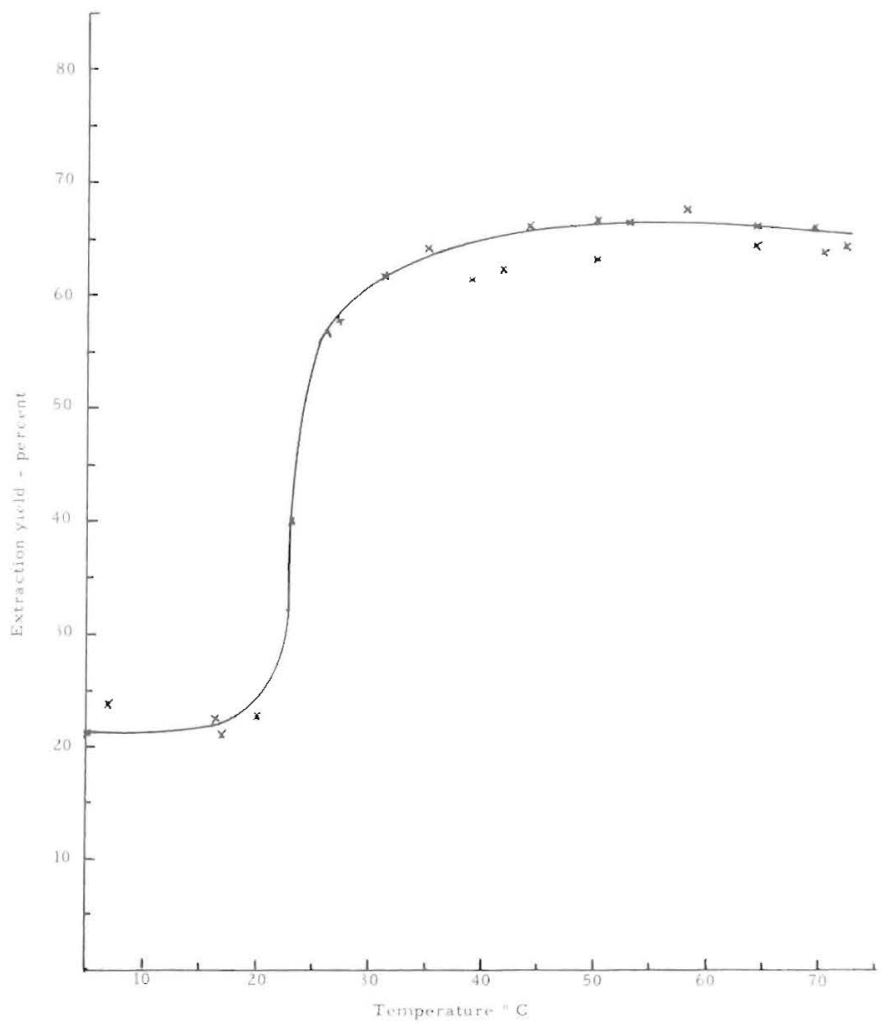

FIG. 1.-Curve showing the effect of temperature of milled pulp on extraction yield of coconut milk.

Although the method using hot water immersion plus warm water gives results as good as the steam treatment plus hot water, the authors are inclined to recommend the steam process. Both methods are industrially sound, but the steam method shows less possibility for contamination.

\section{RESUMEN}

Hay varios factores que afectan la extracción de leche de coco, pues producen variaciones en el rendimiento y en la composición de la leche. En un trabajo anterior del Laboratorio se demostró que con la pulpa de coco congelada se obtiene una leche de baja calidad y que los rendimientos no son satisfactorios. Se encontró además que, subir la temperatura del coco molido antes de prensarlo mejoraba los rendimientos de extracción y a la vez que, el contenido de grasa de la leche era más elevado. Al revisar la literatura no se encontró informatión que estipulara 
el nivel de temperatura óptimo para un rendimiento satisfactorio. Este estudio demuestra una relación del efecto de temperatura en la extracción de leche de coco de pulpa congelada y provee información sobre un posible método para calentarla.

En la primera fase del trabajo, los lotes de pulpa $(8.05 \mathrm{~kg}$.) se pesaron y se molieron en un molino de martillos. La pulpa molida se pesó y se le añandieron $2.04 \mathrm{~kg}$. de agua.

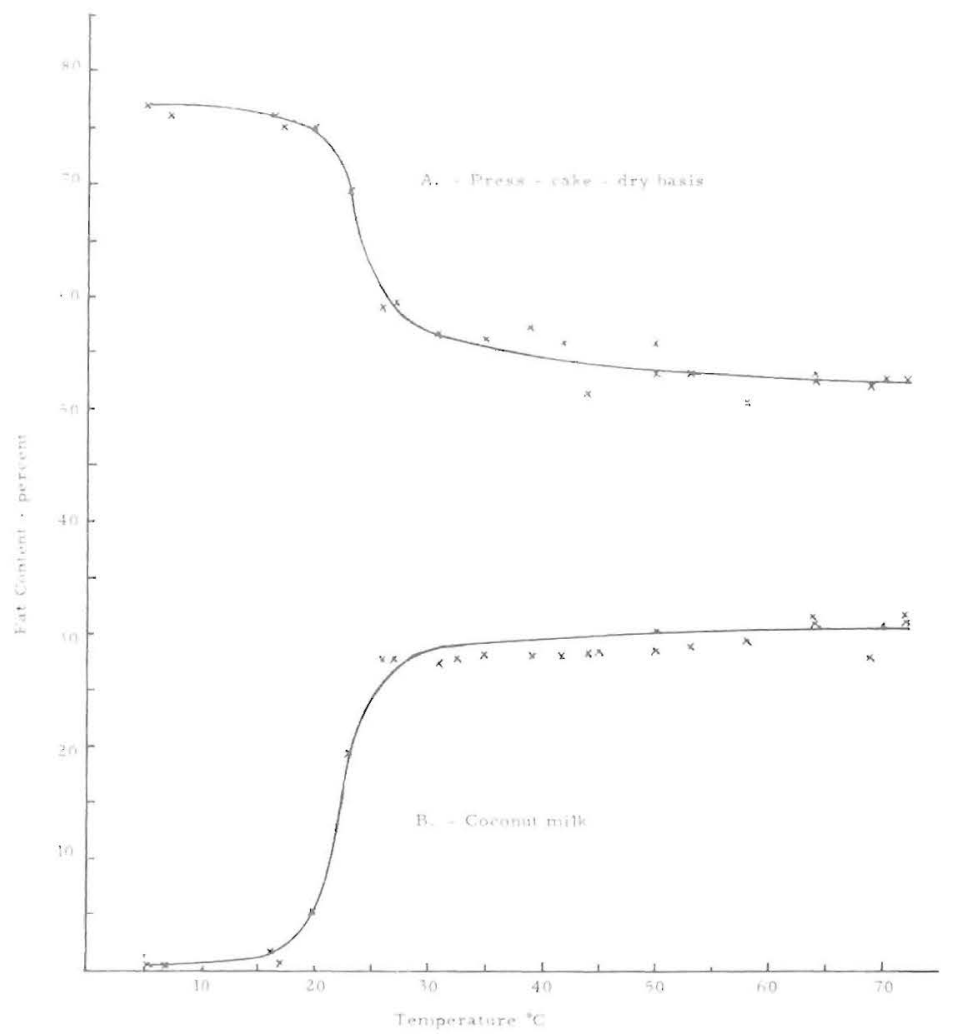

FIG. 2.-Curve showing the effect of temperature of milled pulp on fat content of press-cake and coconut milk.

El coco molido se calentó lentamente en una paila a vapor hasta llevar la pulpa a la temperatura especificada. En esta operación se agitó la pulpa constantemente para conseguir un calentamiento uniforme. Se preparó un lote sin calentamiento, pero en otros, se trató de conseguir una diferencia de $10^{\circ} \mathrm{C}$. entre éstos hasta llegar aproximadamente $70^{\circ} \mathrm{C}$.

La extracción de la leche se hizo en una prensa hidráulica a una presión de $13.0 \mathrm{~kg} . / \mathrm{cm} .^{2}$ 
En la segunda fase los lotes de pulpa congelada se sometieron a un tratamiento de calor antes de molerse. Se usaron dos métodos para calentar la pulpa, los cuales se usan corrientemente en la industria de alimentos. En el primero, la pulpa se sumergió en un tanque de agua caliente (aproximadamente a $98^{\circ}$ C.) por 1, 3, 5 y $10 \mathrm{~min}$. Luego se molió añadiéndole $2.04 \mathrm{~kg}$. de agua a aproximandamete $40^{\circ} \mathrm{C}$.

En el segundo método la pulpa se calentó manteniéndola en una

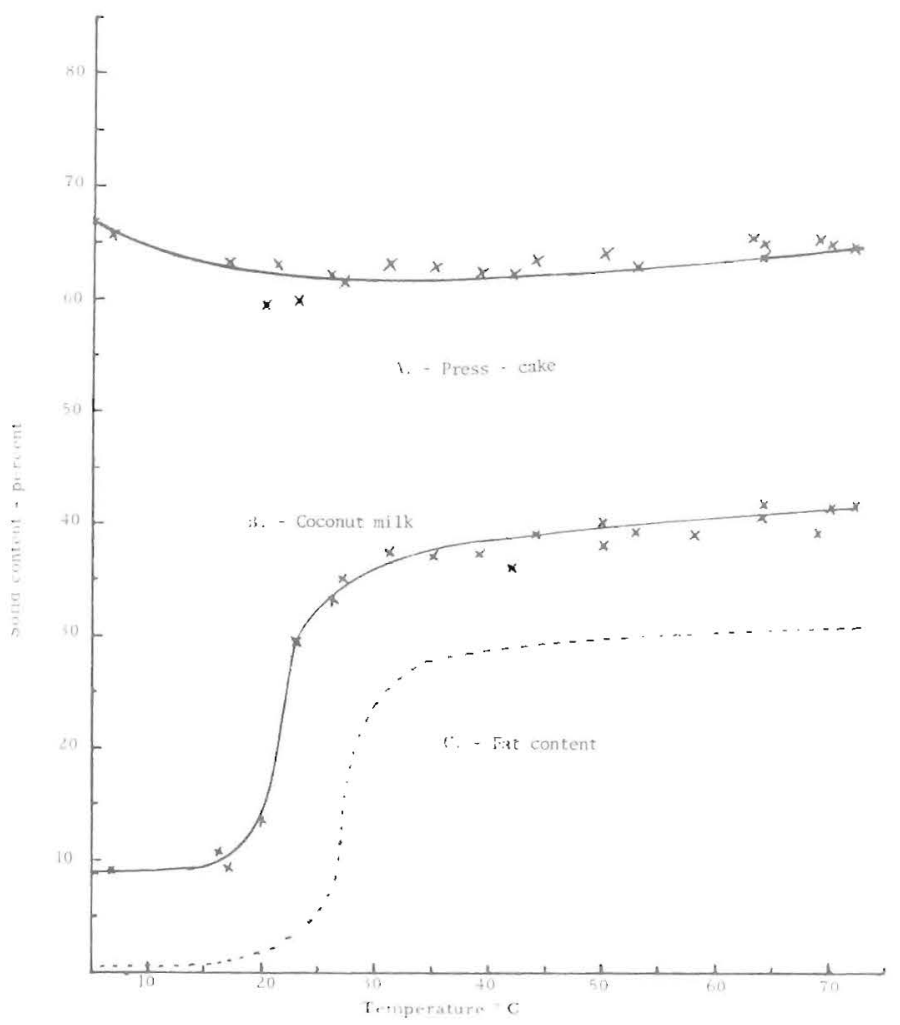

FIG. 3.-Effect of temperature of milled pulp on solid content of press-cake, coconut milk, and fat content.

cámara con vapor por espacio de 1,3 y 5 minutos y moliéndola luego de añadile $2.04 \mathrm{~kg}$. de agua a $40^{\circ} \mathrm{C}$.

Se notó que hubo una pérdida de peso en la pulpa al ésta calentarse y para compensarla se realizaron pruebas añadiéndole agua. Se hicieron pruebas adicionales con el método a vapor, en el cual el agua añadida al moler se calentaba a $98^{\circ} \mathrm{C}$.

La primera fase del estudio reveló que las temperaturas entre $20^{\circ}$ y $35^{\circ}$ 
TABLE 2.-Extraction yield from hot water and steam treatments of frozen pulp before comminution

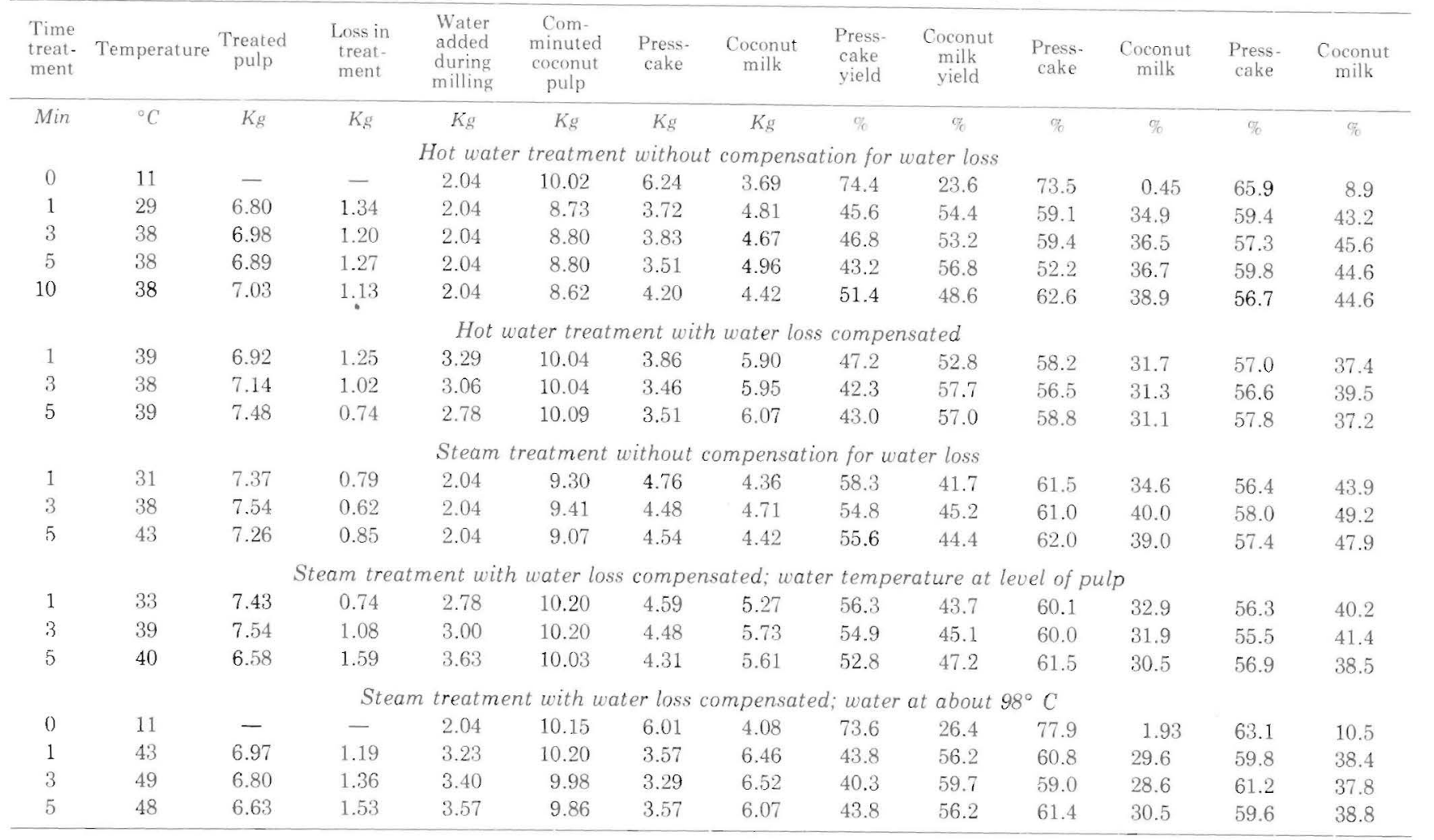




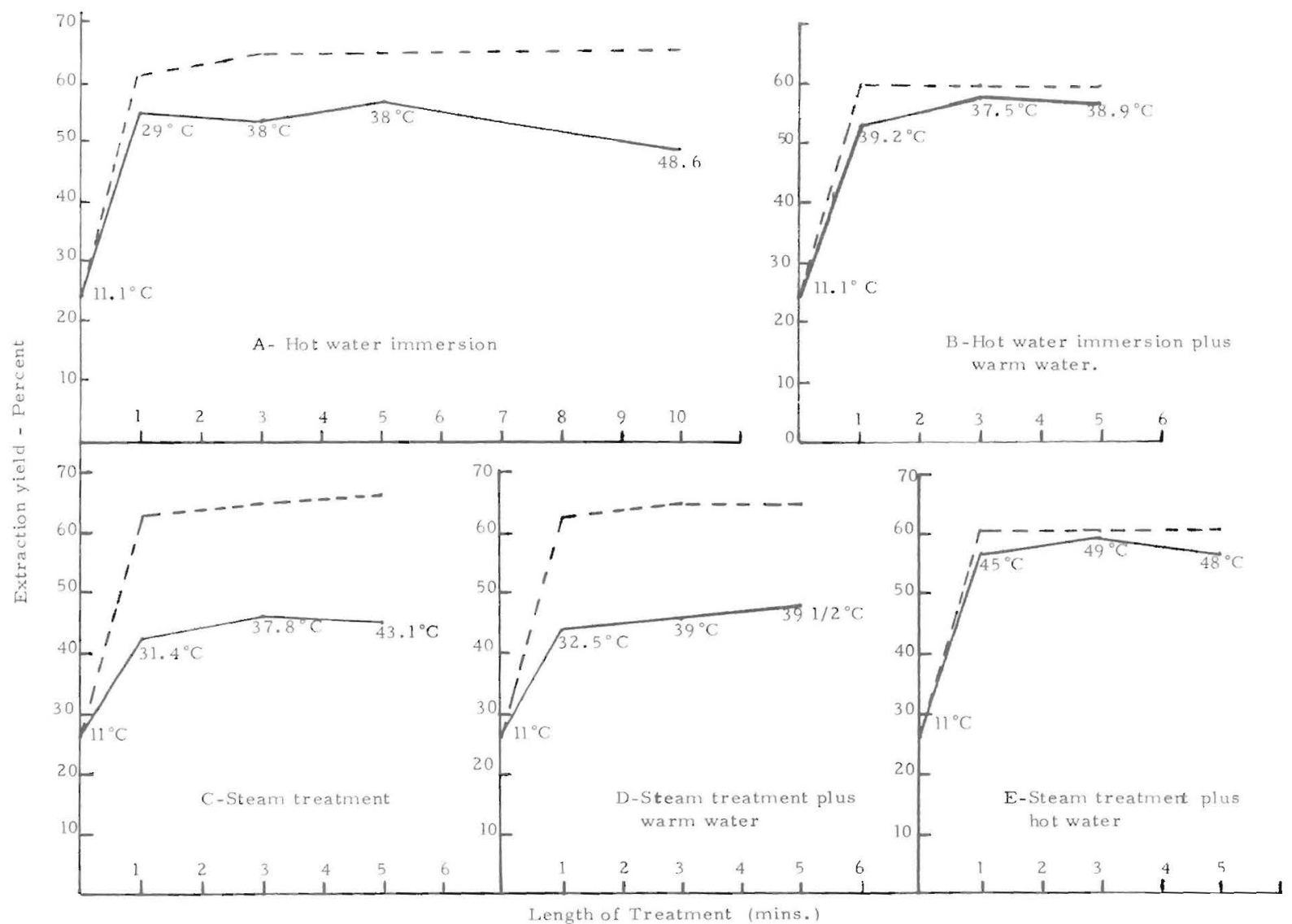

FIG. 4.-Effect of hot water and steam treatment on frozen pulp before comminution (solid line), and the corresponding values of the previous study (fig. 1) (broken line). 
C eran las más críticas para la extracción de leche de la pulpa molida. Con estas temperaturas se obtuvieron rendimientos menores de 25 por 100 y sobre éstas, de 63 por 100. La pulpa de coco molida a temperaturas entre $35^{\circ}$ y $50^{\circ} \mathrm{C}$. dió los mayores rendimientos y una leche con los contenidos más elevados de grasa.

La segunda parte de este trabajo demostró que se puede calentar la pulpa de coco congelada mediante el uso de vapor. En esta operación hubo que compensar con agua adicional el peso perdido en el calentamiento. Además, el agua debe de estar a una temperatura de $98^{\circ} \mathrm{C}$.

El calentamiento a vapor es una operación menos susceptible a contaminación que la inmersión en agua caliente, por lo que se recomienda su uso, añadiendo agua caliente entre $98^{\circ}$ y $100^{\circ} \mathrm{C}$. para limitar las pérdidas de peso.

\section{LITERATURE CITED}

1. Cancel, L. E., Coconut food products and bases, Chapter 9, Coconuts: productionprocessing-products, edited by J. G. Woodroof, Avi Publishing Co., Westport, Conn., pp. 162-88, 1970.

2. —- Rivera-Ortíz, J. M., and R. de Hernández, E., Storage of frozen coconut pulp and quality of coconut milk extracted, J. Agr. Univ. P.R. 60 (1): 99-104, 1976.

3. - Method of shelling coconuts, U.S. Patent 3, 225, 804, 1965.

4. - Coconut breaking machine, U.S. Patent 3, 695, 834, 1969. 